JEL: O13, P28, P32, Q56, Q57

\author{
Svitlana Fedulova ${ }^{1}$, Volodymyr Dubnytskyi, Nataliia Naumenko ${ }^{1}$, \\ Vitalina Komirna ${ }^{2}$, Iryna Melnikova ${ }^{3}$, Batyrhan Agabekov ${ }^{4}$ \\ ${ }^{1}$ Ukrainian State University of Chemical Technology \\ ${ }^{2}$ European Social-Technology University \\ ${ }^{3}$ Kryvyi Rih National University \\ ${ }^{4}$ West Kazakhstan Humanitarian Academy \\ ${ }^{1,3}$ Ukraine \\ ${ }^{2}$ Poland \\ ${ }^{4}$ Kazakhstan
}

\title{
EFFECTIVE ECONOMIC GROWTH UNDER CONDITIONS OF REGIONAL WATER MANAGEMENT DEPENDENCE
}

Purpose. The purpose of the article is an identifying the impact of regional water management dependence on economic growth in the region.

Methodology / approach. The subject of the study is theoretical and methodological basics of a new scientific paradigm for regulation the development of the regional socio-economic systems under the conditions of limited water resources. The study used traditional and special research methods, including: historical and logical - to analyze the evolution of regional socio-economic systems under conditions of limited water resources; abstractions and analogies - to reveal the essence of water-efficient regional socio-economic systems in the modern processes of regionalization and globalization; theoretical generalization, analysis and synthesis - to specify the categorical apparatus; statistical analysis to assess the level of needs of regional socio-economic systems in water resources and create an index of regional water management dependence; method of correlation analysis (biserial correlation, using a point biserial Pearson's correlation coefficient).

Results. The main idea of the paper is to study the issues of development of regional socioeconomic systems under the conditions of limited water resources. Considering this, the paper is aimed at studying the impact of regional water management dependence on economic growth in the region. The tasks for development of regional socio-economic systems on the basis of water efficiency are defined, as well as the concept "water-efficient regional socio-economic system" is defined. The study presents a hypothesis about the need to change the paradigm of regulation of regional development on the basis of water use efficiency and regional water management dependence. In order to trade effectively with the main crops, it is necessary to determine whether there are sufficient water supplies in a given country and its regions. For this purpose, the authors proposes to use own indicator, such as the index of regional water management dependence. The characteristic of water management dependence is given, from regions where only up to half of the water supply of the territory is used, and to regions where more than $100 \%$ of the water supply of the territory is used. The research has updated that the expansion of knowledge and understanding of the specifics of the water sector can solve significant problems. It is proved that the economic growth of the Ukrainian economy due to the agricultural sector has its limits and is limited by the water management dependence of the territories, ie the limitation of certain territories of the regions of Ukraine in terms of water resources. The next effective economic growth is possible only through the implementation of water-efficient technologies and intensification of water-efficient 
activities in the region.

Originality / scientific novelty. The study for the first time defines the concept of waterefficient regional socio-economic system, so it is a socio-economic system that provides for the restoration of water resources in the region, reducing the water intensity of gross regional product $(G R P)$ and approaching European norms and proposes the classification of regions according to the index of regional water management dependence on the basis of its threshold values. A scientific and methodological approach to assessing the level of needs of regional socio-economic systems in water resources has been improved, based on the application of the index of regional water management dependence, which is proposed to calculate the ratio of total fresh water use in the region to the volume of available river runoff in the region (parts of the water potential). The classification of regional socio-economic systems according to the level of water supply has been improved, which is based on the definition of threshold values of the index of regional water management dependence. The methodological bases for assessing the impact of the spatial economy on regional development under conditions of limited water resources have been improved, which differ in substantiating the dependence of the level of development of regions on the available water potential of the territory.

Practical value / implications. The results of the study allow a more comprehensive approach to the study of the problem of using water resources in Ukraine in the context of their limitation. The results of the study showed that the economic complex in most regions is water-intensive and unbalanced, as well as does not provide restoration of water resources by environmental parameters and requires the implementation of infrastructure schemes for redistribution of water resources between regions for economic activity. The results are recommended for consideration by local governments and regional administration for the development and implementation of "Regional programs for the development of water management in the region" and for the development of "Strategies for regional development until 2025-2027".

Key words: growth, region, water, resources, dependence, management.

Introduction and review of literature. In the light of institutional transformations in Ukraine, the formation of a vision of a new significance for a regional economy should become a priority. Taking into account the processes of decentralization, which are now actively implemented in Ukraine, more and more attention is focused on the resource specialization of the region. Perspective resources that will be able to give a big impetus to regional development in the future can be considered water resources, which are considered as an alternative source of energy and are the basis of sustainable development in general. The effectiveness of regional water use differs from water conservation by the fact that it is aimed at reducing waste rather than limiting its use.

As is noted in the 4th World Water Development Report (WWDR4) within the framework of the UN Water Assessment Program, in the future world water resources can be subject to increased pressure. The demand for water is increasing and climate change is expected to threaten its availability (UNESCO-WWAP, 2012). Water is not limited to political boundaries. Experts estimate that international pools are located in 148 countries, 21 of which are completely located inside these basins. In addition, about 2 billion people around the world depend on underground water resources, which include 273 transboundary aquifers. Numerous growth factors driving water use and related uncertainties can challenge existing transboundary agreements (UNESCO-WWAP, 2012). 


\section{Agricultural and Resource Economics: International Scientific E-Journal}

http://are-journal.com

There are four main sources of demand for water:

- agriculture,

- electricity generation,

- industrial use,

- household consumption.

Energy and water are connected in the closest manner. Water is an indispensable production resource for suppliers of primary energy and electricity used for raw material extraction, cooling in heating processes, purification, cultivation of crops for biofuels, and the commissioning of turbines. Energy is needed to ensure the availability and use of water resources by human beings through their selection, transportation, purification, desalination and irrigation.

There is a direct link between water and food production. Cultivation of crops and livestock - processes that require high capacity of water. Agriculture accounts for $70 \%$ of all water selected by the agricultural, municipal and industrial (including energy) sectors. The growing demand for livestock products, in particular, increases the demand for water. It also affects the quality of water, which in its turn reduces its availability. Responsible water management in agriculture will be an important contribution to the global water security of the future (UNESCO-WWAP, 2012).

Water resources are one of the most regulated areas of EU environmental law. Based on the need for a fundamental review of the legislative framework for the development of a new EU water resource policy, as well as consultations with a wide range of specialists, the European Economic Commission has proposed a new framework directive, called Directive 2000/60/ EC of the European Parliament and of the Council on the establishment of the framework for Community action in the field of water policy dated on 23d of October, 2000 (hereinafter referred to as the Water Framework Directive, WFD).

In 2000 Ukraine approving the Concept of Water Management Development of Ukraine by the Resolution of Verkhovna Rada of Ukraine dd. 14.01.2000, determined that the existing in Ukraine powerful economic complex, based on the structure and level of territorial-sectoral water consumption, water utilization and water protection, is volatile, unbalanced, and for ecological parameters does not correspond to the possibilities of water resources restoration, and also determined the need to include environmental priorities in socially oriented measures of a market economy (Fedulova and Pivovarov, 2017).

The analysis of global trends for the period up to 2030 shows that demand for water resources will increase significantly due to an increase in the population of the planet. In this regard, in the scientific circle, increasingly, the concept of water security is introduced. In 2009, the World Economic Forum gave priority to water security as a global risk by stating that "water security is a thread that brings together food, energy, climate, economic growth and human security challenges that the world economy faces during the next decade" (van Beek \& Linclahen Arriens, 2014).

According to estimates by the National Intelligence Council of the USA, the demand for food by 2030 will grow by 35 percent, while water will rise by 40 . 


\section{Agricultural and Resource Economics: International Scientific E-Journal}

http://are-journal.com

Almost half of the world's population will live in areas that suffer from a severe shortage of freshwater (National Intelligence Council of the USA, 2013).

The world scientific community began to use the term "water security" much earlier than the Ukrainian scientific world. At the 2nd World Water Forum in 2000, the World Water Council presented its vision of "the world of water security - a vision for the sake of water, life and the environment". The Global Water Partnership (GWP) published a paper entitled "Towards Achieving Water Security: Platform for Action".

Consequently, the technical committee of the Global Water Partnership presented the definition of the term "water security", namely: "Water security, at any level, from domestic to global, means that everyone has access to a sufficient amount of safe water at an affordable price for clean, healthy and productive life, while ensuring the protection of the environment" (van Beek \& Linclahen Arriens, 2014).

On May 25, 2016, the Global Water Partnership of Ukraine and the Institute of Water Problems and Melioration of NAAS conducted the Second National Political Dialogue on discussing issues of achieving water security in the agricultural sector of the country and managing droughts as important components of the country's food security in conditions of climate change.

It is worth noting that in Ukraine a new scientific concept of "water security" begins to emerge, which is closely linked both to the economic security of regional state systems and with national security. This scientific field, of course, requires the formulation of research tasks, the development of methods for analysis and evaluation, as well as the related thresholds, the mechanism for implementing the water security system in order to ensure an adequate response to destabilizing factors and the preservation of economic development of the state.

Thus, generalizing the world tendencies of spatial development and tendencies of economic development in Ukraine, one can state that there is a problem of effective regional water use. The main activities and documents that update the study of this problem are presented in Table 1.

Thus, it is clear from Table 1 that humankind originally belonged to water as a common good, not understanding its limitations and possible global scenarios for the development of the world. But in 1992, at the 1st World Water Forum in Marrakesh (Morocco), it was proclaimed that "water is a marketable, expensive commodity that can be waged for war". Since 2000, at the 2nd World Water Forum in The Hague (Netherlands), for the first time, it was raised the issue about the world of water security. In the future, this vision began to be developed. In the EU summit in Brussels in 2012, the Concept "20/20/20" was adopted, which included the vision of water as energy.

Consequently, the world trends in spatial development demonstrate the need to take into account water scarcity, on the one hand, in developing a regional development regulatory policy and their prospect of effective use on the other. Priority is given to the problem of infrastructure provision on the path to regional and national growth (Morris \& McGuinness, 2019; Mishra, Palleti \& Mathur, 2019). 


\section{The main events and documents that update the research of the problem of effective regional water use}

\begin{tabular}{|c|c|c|}
\hline Measures or documents & Year & Main thesis \\
\hline 1 & 2 & 3 \\
\hline \multicolumn{3}{|r|}{ All the world } \\
\hline $\begin{array}{l}\text { United Nations Conference } \\
\text { on Water Resources in Mar } \\
\text { del Plata } \\
\text { (Argentina) }\end{array}$ & 1977 & $\begin{array}{l}\text { All people, regardless of the stage of their development and their } \\
\text { social and economic conditions, have the right of access to drinking } \\
\text { water that meets the needs of quality and quantity. Water is defined } \\
\text { as a common good. }\end{array}$ \\
\hline $\begin{array}{l}\text { United Nations Conference } \\
\text { on Environment and } \\
\text { Development in Rio de } \\
\text { Janeiro (Brasil) }\end{array}$ & 1992 & $\begin{array}{l}\text { Main document: Agenda for the 21st Century: } \\
\text { - global management of fresh water; } \\
\text { - integration of sectoral water management plans and programs } \\
\text { within the framework of national social and economic policy. Water } \\
\text { has no high priority. }\end{array}$ \\
\hline $\begin{array}{l}\text { 1st World Water Forum in } \\
\text { Marrakesh (Morocco) }\end{array}$ & 1997 & $\begin{array}{l}\text { Water is a market, expensive commodity, for which war can } \\
\text { be waged. }\end{array}$ \\
\hline $\begin{array}{l}\text { 2nd World Water Forum in } \\
\text { the Hague (the } \\
\text { Netherlands) }\end{array}$ & 2000 & $\begin{array}{l}\text { The World Water Council presented its vision of "the world of } \\
\text { water security - a vision for the sake of water, life and the } \\
\text { environment". The Global Water Partnership (GWP) published a } \\
\text { paper entitled "Towards Achieving Water Security: Platform for } \\
\text { Action". Water is defined as absolutely necessary element for the } \\
\text { life of both humanity and ecosystems, and as a fundamental } \\
\text { condition for the development of countries. }\end{array}$ \\
\hline $\begin{array}{l}\text { Framework Directive } \\
\text { 2000/60 / EC of the } \\
\text { European Parliament and } \\
\text { of the Council establishing } \\
\text { a framework for } \\
\text { Community action in the } \\
\text { field of water policy } \\
\text { (Water Framework } \\
\text { Directive) }\end{array}$ & 2000 & $\begin{array}{l}\text { This directive has accelerated the historical process of managing } \\
\text { transboundary water resources. }\end{array}$ \\
\hline $\begin{array}{l}\text { Millennium Summit } \\
\text { in New York (the USA) }\end{array}$ & 2000 & $\begin{array}{l}\text { The Millennium Development Goals are defined: "By } 2015 \text {, to } \\
\text { halve the proportion of people without access to safe drinking } \\
\text { water". }\end{array}$ \\
\hline $\begin{array}{l}\text { 4th World Water Forum in } \\
\text { Mexico City (Mexico) }\end{array}$ & 2006 & $\begin{array}{l}\text { Key messages are defined: } \\
\text { - ensuring water security and development require a minimum } \\
\text { level of water infrastructure; } \\
\text { - corruption is a barrier to achieving water security; } \\
\text { - governments bear primary responsibility for the } \\
\text { implementation of the right to water for all; } \\
\text { - financing access to water for all requires solidarity and new } \\
\text { mechanisms. }\end{array}$ \\
\hline World Economic Forum & 2009 & $\begin{array}{l}\text { Highlighting the priority of water security as a global risk, said } \\
\text { that "water security is a thread that connects food, energy, climate, } \\
\text { economic growth and human security challenges that the world } \\
\text { economy faces over the next decades". }\end{array}$ \\
\hline $\begin{array}{l}\text { Forecasts of the } \\
\text { Intergovernmental Panel } \\
\text { on Climate Change (IPCC) }\end{array}$ & $\begin{array}{c}2010- \\
2012\end{array}$ & $\begin{array}{l}\text { It is noted that water shortages in Central and Southern Europe } \\
\text { will increase, and by } 2070 \text { the number of people worried about this } \\
\text { problem will grow by } 16-44 \mathrm{mln} \text {. }\end{array}$ \\
\hline
\end{tabular}


Continuation of Table 1

\begin{tabular}{|c|c|c|}
\hline 1 & 2 & 3 \\
\hline $\begin{array}{l}\text { Estimates of the US } \\
\text { National Intelligence } \\
\text { Council }\end{array}$ & $\begin{array}{c}2010- \\
2013\end{array}$ & $\begin{array}{l}\text { Demand for food will rise by } 35 \text { percent by } 2030 \text {, and by } \\
40 \text { percent by water. Almost half of the world's population will live } \\
\text { in areas that suffer from a severe shortage of freshwater. }\end{array}$ \\
\hline $\begin{array}{l}\text { 6th World Water Forum in } \\
\text { Marseille (France) }\end{array}$ & 2012 & $\begin{array}{l}\text { Theme of the forum: "Water resources management in } \\
\text { conditions of uncertainty and risk". It has been determined that } \\
\text { water is at the heart of all aspects of development: it is the only } \\
\text { "intermediary" that connects various sectors of the economy and } \\
\text { whose joint role can be managed by all sides of the global crisis } \\
\text { together. Water is a key element of "green growth" and } \\
\text { development of the "green economy". }\end{array}$ \\
\hline $\begin{array}{l}\text { The 4th World Water } \\
\text { Development Report } \\
\text { (WWDR4) within the UN } \\
\text { Water Assessment } \\
\text { Program }\end{array}$ & 2012 & $\begin{array}{l}\text { Determined that in the future world water resources can be } \\
\text { subjected to increased pressure. The demand for water is increasing } \\
\text { and climate change is expected to threaten its availability. }\end{array}$ \\
\hline Саміт СС у Брюсселі & 2012 & Concept " $20 / 20 / 20$ ". Water is consic \\
\hline $\begin{array}{l}\text { Water Forum in } \\
\text { orea) }\end{array}$ & 2015 & $\begin{array}{l}\text { Launching the report "Water: Approach to Financing?", The } \\
\text { World Water Council demonstrated the growing need for } \\
\text { investment in large water infrastructure schemes as a means of } \\
\text { stimulating national growth. With increasing use of water for all } \\
\text { types of activities - agriculture, industry, energy - water } \\
\text { infrastructure should be multipurpose. }\end{array}$ \\
\hline $\begin{array}{l}\text { ter Forum in } \\
\text { 1) } \text { for 2021) }\end{array}$ & 2018 & $\begin{array}{l}\text { The 8th World Water Forum } 2018 \text { in Brazil was held under the } \\
\text { general theme "Water Sharing". At the World Water Forum, UN } \\
\text { experts declared that the world is on the brink of water disaster. }\end{array}$ \\
\hline \multicolumn{3}{|r|}{ Ukraine } \\
\hline $\begin{array}{l}\text { Concept of development of } \\
\text { water economy of Ukraine, } \\
\text { approved by the } \\
\text { Verkhovna Rada of } \\
\text { Ukraine dd.14.01.2000 }\end{array}$ & 2000 & $\begin{array}{l}\text { Determined that the existing powerful economic complex in } \\
\text { Ukraine, based on the structure and level of territorial-sectoral water } \\
\text { consumption, water use and water protection technologies, is water- } \\
\text { insensitive, unbalanced, and according to environmental parameters } \\
\text { does not correspond to the possibilities of water resources } \\
\text { restoration, and also determined the need to include environmental } \\
\text { priorities in socially-oriented measures of the market economy. }\end{array}$ \\
\hline $\begin{array}{l}\text { State Strategy for Regional } \\
\text { Development for the } \\
\text { period till 2020, approved } \\
\text { by the Resolution of the } \\
\text { Cabinet of Ministers of } \\
\text { Ukraine dd. August } 6 \text {, } \\
2014 \text { No. } 385\end{array}$ & 2014 & $\begin{array}{l}\text { Determined the influence of global trends in spatial } \\
\text { development, in particular, the financial and economic crisis and the } \\
\text { limited resources (primarily water), the growth of world food needs, } \\
\text { the orientation of the territory that are the largest producers of food. }\end{array}$ \\
\hline $\begin{array}{l}\text { The Global Water } \\
\text { Partnership of Ukraine and } \\
\text { the Institute of Water } \\
\text { Problems and Amelioration } \\
\text { of the National Academy } \\
\text { of Sciences of Ukraine }\end{array}$ & 2016 & $\begin{array}{l}\text { Conducted the Second National Political Dialogue devoted to } \\
\text { discussing the issues of achievement of water security in the } \\
\text { agricultural sector of the country and the management of droughts } \\
\text { as the important components of the country's food security in } \\
\text { conditions of climate change. }\end{array}$ \\
\hline
\end{tabular}

Source: prepared by authors, according to data of World Water Council (2016), van Beek \& Linclahen Arriens (2014), National Intelligence Council of the USA (2013), UNESCO-WWAP (2012), Cabinet of Ministers of Ukraine (2017), Fedulova \& Pivovarov (2017).

According to the authors, water can be considered in several directions, namely: Water is a common good; a market, as it is an expensive product; a productive 


\section{Agricultural and Resource Economics: International Scientific E-Journal}

http://are-journal.com

resource (primarily energy); a safety factor.

The problem of water resource allocation and its efficient use refers to regional problems in Ukraine, especially in the world of decentralization.

The conducted review of scientific sources allows us to state the existence of an important scientific problem of effective regional water use taking into account infrastructure provision and compliance with the requirements of global water security of the future on the way of stimulating regional and national growth.

Over the past decades, the concept of food security, energy security and access to natural resources has been widely discussed. However, to date, more researchers are recognizing that the environment and security are interconnected. In particular, on the example of water resources, it can be argued that the deficit of fresh water represents both a direct and an indirect threat to safety, because on the one hand, as a result of this deficit there is a dangerous situation, and on the other hand, it is fraught with potential conflicts (Wehn \& Montalvo, 2018; Bretschger \& Vinogradova, 2019).

With the growth of water scarcity in a number of countries, recently due to global warming, a number of strategies have been developed to overcome it, which include savings on water consumption, saltinen or salty sea water desalination (Melina, Yang \& Zanna, 2016). Another alternative is to minimize water consumption by importing water-based products - both agricultural and industrial, including energy. This thesis explains the concept of "virtual water", which was developed in 1993 by the author of the concept of "virtual water" related to measuring the volume of water embodied in products and trade in food and other consumer goods, is a professor of the London University John Antony Allan (1998). He proposed a formula for calculating the amount of water needed to produce a particular product. This concept helps to understand how much water is needed in order to make different goods and services. The concept of "virtual water" has allowed a new look at issues of effective water use and water policy.

Water is usually not transported directly over long distances. Despite the fact that some cases of direct export of water are already fixed, there is neither the world market nor the standard global price of water. Instead, international trade in voluminous goods, the so-called virtual water market, already exists (Oki et al., 2017; Wichelns, 2010; OECD, 2015; Perelyot, 2010). As a rule, it is considered that trade in "real water" between territories without moisture is impossible due to long distances and associated costs, as well as because water as a productive resource is required to a large extent (Oki et al., 2017). International water trade through the construction of canals and the redistribution of river flows is very limited due to huge capital expenditures.

It should be noted that the problems of export-import of "virtual water" are extremely worried by the Food and Agriculture Organization of the United Nations (FAO, 2017), the World Water Institute (SIWI, 2017), the Institute of World Resources (WRI, 2017), and many European researchers.

More and more we recall the statement of World Bank Vice-President I. Seragildin: "The Wars of the Twenty-first Century will be the wars for water", 


\section{Agricultural and Resource Economics: International Scientific E-Journal}

http://are-journal.com

which he proclaimed in 1995 (Dinar, 2007).

For arid countries, the import of virtual water (first of all, in the form of agricultural products, which accounts for up to $70-90 \%$ of water consumption, can be a good means of reducing domestic demand for water and, thus, mitigating the internal water shortage.

It should be noted that there are many factors that affect the flow of water-based products, which are many times more important than the water supply factor.

Thus, the question arises as to how water security determines the specialization of the region on the export or import of water-based products in the real practice of international trade.

A study conducted in 2003 by X. Yang and co-authors (Yang et al., 2003), which, after analyzing data on the countries of Africa and Asia, argues that for most countries, the degree of water availability is not a significant factor affecting international trade. However, after reaching a certain threshold for a shortage of water, the country begins to demand the import of cereals, which exponentially grows as water resources diminish. Later, researchers conclude that reducing water availability is an important factor in the growth of net imports of virtual water by countries in the region (Yang et al., 2007).

$\mathrm{X}$. Yang's with co-authors research, allows us to trace the dynamics of the relationship between water resources supply and its trade specialization.

The purpose of the article is an identifying the impact of regional water management dependence on economic growth in the region.

Results and discussion. According to researchers from the University of Leiden, the Netherlands, by 2017, Ukraine is the world's largest food exporter, along with the United States (mainly South America), Australia and Russia. But the main importers of food products are Western Europe, Asia and Africa and the Middle East (Bacon, 2017).

It is a reason to worry that Ukraine is not a country with rich water potential, it is the poorest country in water resources among European countries $\left(52.4 \mathrm{~km}^{3} / \mathrm{year}\right.$ of average annual resources of river runoff). As well as Pakistan, which owns $55 \mathrm{~km}^{3} /$ year of average annual resources of river flow. Ukraine belongs to the least water-dependent countries of Europe, since the stock of local resources of river runoff per person is about 1.0 thsd. cubic meters per year (Jacyk et al., 2017).

The river runoff during the last 8 years is fixed by scientists as unchanged in Ukraine. Earlier publications on geography textbooks also point to an unchanged number of river flows. Confirmation of the constancy of the river flow in Ukraine and the data of the site of the Food and Agriculture Organization of the United Nations (FAO), which publishes that from 1992 to 2014 the river runoff in Ukraine is $55.1 \mathrm{~km}^{3} /$ year (2017). However, calculations of this flow per person are made taking into account the current population of Ukraine (Table 2).

The largest amount of water resources $(58 \%)$ is zoned in rivers of the Danube basin in the border regions of Ukraine. The least water resources are Donbass, Krivorozhya, Autonomous Republic of Crimea and other southern regions of 
Ukraine, where the largest water users are concentrated. The minimum level of water security, defined by the UN, it is 1.7 thsd. $\mathrm{m}^{3}$ per year per person. In Ukraine, this figure is only 1.0 thsd. $\mathrm{m}^{3}$ (Jacyk et al., 2017).

Table 2

Water supply of regions of Ukraine per 1 person, thsd. $\mathrm{m}^{3} /$ year

\begin{tabular}{|c|c|c|c|c|}
\hline \multirow[t]{3}{*}{ Regions } & \multicolumn{3}{|c|}{$\begin{array}{l}\text { Provision of average perennial river } \\
\text { runoff of } 1 \text { person, thsd. } \mathrm{m}^{3} / \text { year }\end{array}$} & \multirow{3}{*}{$\begin{array}{c}\begin{array}{c}\text { Average number of } \\
\text { permanent population, } \\
\text { thsd. people }\end{array} \\
2017^{1}\end{array}$} \\
\hline & 2007 & 2015 & $2017^{1}$ & \\
\hline & \multicolumn{3}{|c|}{ local } & \\
\hline Ukraine & 1.08 & 1.23 & 1.24 & 42315.836 \\
\hline Crimea & 0.38 & - & - & - \\
\hline Vinnytsia & 1.39 & 1.54 & 1.57 & 1575.997 \\
\hline Volyn & 2.06 & 2.09 & 2.10 & 1036.977 \\
\hline Dnipro & 0.24 & 0.27 & 0.27 & 3227.466 \\
\hline Donetsk & 0.21 & 0.24 & 0.24 & 4209.374 \\
\hline Zhytomyr & 2.27 & 2.52 & 2.55 & 1236.629 \\
\hline Zakarpattya & 6.29 & 6.29 & 6.31 & 1255.633 \\
\hline Zaporizhzhia & 0.32 & 0.35 & 0.36 & 1730.540 \\
\hline Ivano-Frankivsk & 3.26 & 3.32 & 3.34 & 1375.979 \\
\hline Kyiv & 0.46 & 0.44 & 0.44 & 4627.433 \\
\hline Kyrovohrad & 0.84 & 0.98 & 1.00 & 954.588 \\
\hline Luhansk & 0.57 & 0.66 & 0.67 & 2176.949 \\
\hline Lviv & 1.87 & 1.94 & 1.96 & 2513.448 \\
\hline Mykolaiv & 0.45 & 0.49 & 0.50 & 1145.010 \\
\hline Odesa & 0.14 & 0.15 & 0.15 & 2373.736 \\
\hline Poltava & 1.19 & 1.35 & 1.37 & 1412.491 \\
\hline Rivne & 1.98 & 2.01 & 2.01 & 1160.645 \\
\hline Sumy & 1.88 & 2.20 & 2.23 & 1097.215 \\
\hline Ternopil & 1.58 & 1.70 & 1.72 & 1052.501 \\
\hline Kharkiv & 0.56 & 0.61 & 0.62 & 2681.962 \\
\hline Kherson & 0.12 & 0.13 & 0.13 & 1049.883 \\
\hline Khmelnytsk & 1.5 & 1.65 & 1.68 & 1276.675 \\
\hline Cherkasy & 0.72 & 0.81 & 0.83 & 1222.156 \\
\hline Chernivtsi & 1.33 & 1.35 & 1.36 & 904.346 \\
\hline Chernihiv & 2.77 & 3.30 & 3.39 & 1018.203 \\
\hline
\end{tabular}

Note. ${ }^{1}$ Data are given without taking into account the temporarily occupied territory of the Autonomous Republic of Crimea and the city of Sevastopol.

Source: prepared by authors, according to data of Jacyk, Grishchenko et al. (2017); Jacyk Tomiltseva et al. (2007); State Statistics Service of Ukraine (2018).

In the context of the regions, according to the UN methodology, sufficient river runoff is formed only in 8 regions - Volyn, Zhytomyr, Zakarpattya, Ivano-Frankivsk, Lviv, Rivne, Sumy and Chernihiv, which exceeds 1.7 thsd. $\mathrm{m}^{3}$ per year by 1 person.

With the decrease of the population in Ukraine, of course, there is an increase in river flow per person. In 2017 already exceeded the threshold value of the river runoff and Ternopil region.

As already described, the largest volumes of water consumption is for the 


\section{Agricultural and Resource Economics: International Scientific E-Journal}

http://are-journal.com

production of grain and agricultural products. Compared to 1990, the highest growth rates were recorded for grain and legume crops in Ukraine and sunflower, respectively, by $121.38 \%$ and $475.94 \%$, that is, over the years of independence, grain and legume production increased 1.2 times, while sunflower seeds were almost by 4.8 times

If to investigate in the context of the last 10 years, then from 2007 to 2017 grain and legume production has already increased by 2.1 times, so there is a tendency to increase this production.

This dynamic studied since 1940 indicates that Ukraine only increased grain and legume production from 26419.7 thsd. tons in 1940 to 61916.7 thsd. tons in 2017 (in 2.3 times) and sunflower from 946.5 thsd. tons in 1940 to 12235.5 thsd. tons in 2017 (13 times).

The results of the research carried out by the working group of nongovernmental organizations on climate change show that the climate of Ukraine has already started to change over the past decades (temperature and some other meteorological parameters are different from the values of the climate norm).

Against the background of building up the agrarian potential described above, in Ukraine since 1990 and to nowadays there has been a significant reduction in the volume of water use (compared with 1990 almost by four times) and a corresponding reduction in the technogenic load on water objects. There are several reasons for this: firstly, the reduction of national production is due to the reorientation of production to the domestic market during the crisis years 1991-1996, and secondly, the moral and physical aging of equipment and wastewater treatment systems over time, which also led to the decline of national production, and, of course, thirdly, the use of waterefficient technologies in recent years (technology of consistent recycled water supply on production, closed technologies) has to be taken into account.

A new scientific paradigm for regulating the development of regional social and economic systems based on the consideration of the limited water resources.

Takung into account nature of the region as a system and the need to take into account effective regional water use, the functioning of these systems changes the paradigm of regulation of regional development, namely, the authors proposes a new scientific paradigm for regulating the development of regional social and economic systems based on the consideration of the limited water resources, which is to consider them as a productive resource, a market commodity, a common economic good and a safety factor. The aim of the paradigm is to ensure a high level of wellbeing of the population by stimulating the water efficient activity of the regional socio-economic system on the basis of the development of infrastructure support for the reproduction of water resources.

Thus, the authors defines the concept of a water-efficient regional social and economic system - a socio-economic system that provides for the restoration of water resources in the region, reducing the water intensity of gross regional product (GRP) and approaching European norms.

In this study we have identified the following principles of a water-efficient 
regional social and economic system:

1. Principle of natural conformity;

2. Principle of system integrity and integrity;

3. Principle of synergetics;

4. Principle of balance;

5. Principle of the global water problems.

The authors emphasizes that the territories in their economic development shall adhere to the stated principles of a water-efficient regional social and economic system.

In order to conduct effective trade in major crops, it is necessary to determine whether there are sufficient water supplies in the country and its regions. To do this, the authors propose to use their own indicator, such as the index of regional water management dependence, which is proposed to be calculated as the ratio of total fresh water use in the region to the volume of available river runoff in the region (as the main part of water potential). Values greater than 1 will indicate a mismatch in the region's water recovery capacity.

As a value of the volume of available river runoff of a certain region, we have chosen the value of the "local" average perennial river runoff in the region. As already mentioned, such runoff in Ukraine is $52.4 \mathrm{~km}^{3} /$ year of average perennial river runoff. This value is used as such, which is formed exclusively within Ukraine in the average water year. It is known that the lands of Ukraine belong to the zone of risky agriculture and are characterized by significant droughts.

In general, long-term observations indicate that in the average water year the potential resources of river waters in Ukraine are $88 \mathrm{~km}^{3} / y e a r$ ("total" average perennial river runoff), of which $52.4 \mathrm{~km}^{3} /$ year ("local" average perennial river runoff) are formed within Ukraine. In a low-water year, such resources are much smaller and amount to $56 \mathrm{~km}^{3} /$ year and $32 \mathrm{~km}^{3} /$ year, respectively (Jacyk et al., 2017).

Given the fact that the lands of Ukraine belong to the zone of risky agriculture and the fact that most agricultural regions, according to the UN methodology, do not have a minimum level of water supply ( 1.7 thsd. $\mathrm{m}^{3}$ per year per person), we have chosen the value of "local" average perennial river runoff in the region to calculate the index of regional water management dependence.

It should be noted that the Food and Agriculture Organization of the United Nations (FAO) uses the water stress index for a similar purpose, which is defined as the ratio between total water intake and available freshwater resources. In its calculations, the organization uses the value of the "total" average perennial river runoff. But, in our opinion, given the limited water resources of Ukraine, the use of the value of the "total" average perennial river runoff is unacceptable. Because, as already mentioned, the lands of Ukraine belong to the zone of risky agriculture, are characterized by significant droughts, most agricultural regions, according to the UN methodology, do not have a minimum level of water supply, and recent years in Ukraine are characterized by low water - this is $32 \mathrm{~km}^{3} /$ year of river runoff instead of $88 \mathrm{~km}^{3} /$ year, which are used in the calculations of water stress. 
Thus, using the statistics of the State Statistics Committee of Ukraine, the calculation of the index of regional water management dependence by the formula:

$$
I_{\text {rwd }}=\frac{V_{\text {used water }}}{V_{\text {riverrunoff }}}
$$

where $\mathrm{V}_{\text {used water }}$ - full use of fresh water in the region, $\mathrm{km}^{3}$;

$\mathrm{V}_{\text {river runoff }}$ - volume of available river runoff of this region, $\mathrm{km}^{3}$.

Index of regional water management dependence.

From the assumption that in the last 10 years (2007-2017) river runoff is unchanged, we will calculate the index of regional water management dependence according to the proposed formula (data on the use of fresh water in 2007-2016 by regions is taken from statistical reports) (Fig. 1).

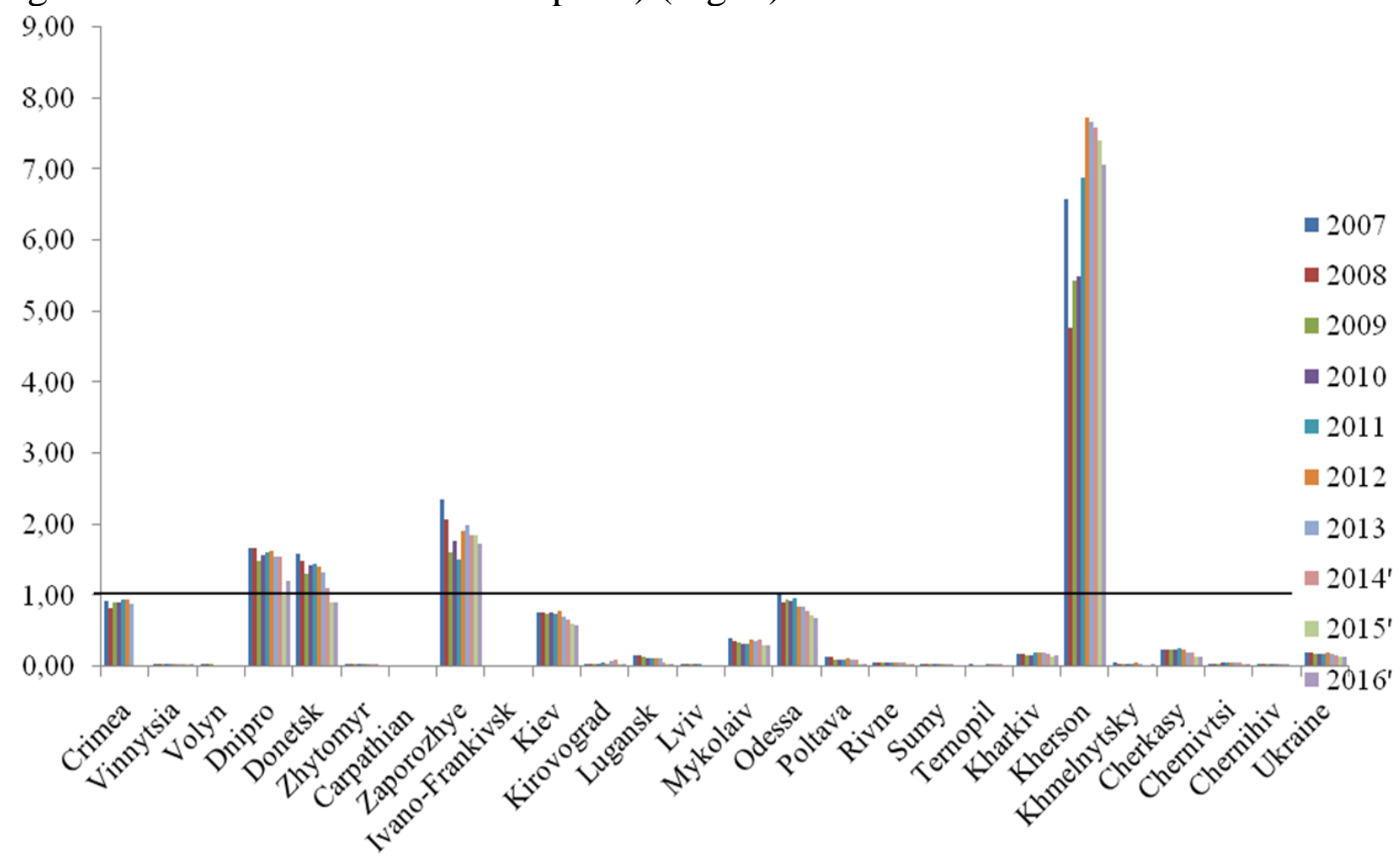

Fig. 1. Index of regional water management dependence

Source: author's calculations.

The Dnipro, Donetsk, Zaporizhzhia and Kherson regions are invariably the territories that have a critical value of the index of regional water management dependence for the last 10 years. Kherson region over this index exceeds other territories with critical values of almost 5-7 times.

The high level of the index of regional water management depend on Odesa and Kyiv regions along with Kyiv, as well as the temporarily occupied territory of the Autonomous Republic of Crimea from Sevastopol. The calculations for the Kyiv region and the city of Kyiv were carried out by summing the values, as for the Autonomous Republic of Crimea from the city of Sevastopol, as statistics of the river runoff are conducted only in the regions with their cities inclusive.

Thus, it is obvious that the economic complex of Ukraine is voluminous and 
unbalanced, and also does not correspond to the possibilities of water resources restoration according to environmental parameters. We will introduce the following classification of regions according to the index of regional water-dependent dependence (Table 3).

Table 3

Threshold values of the index of regional water management dependence

\begin{tabular}{|c|c|l|l|}
\hline Values Irwd & $\begin{array}{c}\text { Characteristics of } \\
\text { water-dependent } \\
\text { dependence }\end{array}$ & $\begin{array}{c}\text { Characteristics of the territory } \\
\text { by value } I_{\text {rwd }}\end{array}$ & \multicolumn{1}{|c|}{ Regions of Ukraine } \\
\hline $0-0.5$ & Low & $\begin{array}{l}\text { Used only to half of the water } \\
\text { supply of the territory }\end{array}$ & $\begin{array}{l}\text { The rest of the other } \\
\text { regions }\end{array}$ \\
\hline $0.51-0.7$ & Average & $\begin{array}{l}\text { Used from } 51 \text { to } 70 \% \text { of the } \\
\text { water supply area }\end{array}$ & No category of addiction \\
\hline $0.71-1.0$ & High & $\begin{array}{l}\text { Used from } 71 \text { to } 100 \% \text { of the } \\
\text { water supply of the territory }\end{array}$ & $\begin{array}{l}\text { Autonomous Republic of } \\
\text { Crimea and the city of } \\
\text { Sevastopol, city of Kyiv, } \\
\text { Kyiv and Odesa regions }\end{array}$ \\
\hline 1.0 and $>$ & Deficit & $\begin{array}{l}\text { Used more than } 100 \% \text { of the } \\
\text { water supply of the territory. } \\
\text { Needed significant infrastructure } \\
\text { schemes for the redistribution of } \\
\text { water resources between regions } \\
\text { for economic activity }\end{array}$ & $\begin{array}{l}\text { Dnipro, Donetsk, } \\
\text { Zaporizhzhia and Kherson } \\
\text { regions }\end{array}$ \\
\hline
\end{tabular}

Source: author's calculations.

It is clear that the resource availability of these territories as black earth and various subsoil and determines the vector of management of these territories. Accordingly, having such a resource potential, but without significant water supply, these areas are unlikely to change their economic vector in the near future, but they need to reflect on sustainable development in the future using water-efficient technologies.

The calculations of the authors confirm the research of the Institute of World Resources, which also includes the Autonomous Republic of Crimea, Kherson, Donetsk, Dnipro (small part) and Odesa (small part) of the region to areas with high water risk. However, the study of this institute focuses on climate change and its impact on the restoration of world water resources. But, the index of regional waterrelated dependence indicates the natural correspondence of the economic complex of the region. Thus, territories that do not comply with principle of natural conformity are Dnipro, Donetsk, Zaporizhzhia and Kherson regions. These areas have the characteristic of water management dependence "deficit", which means that they use more than $100 \%$ of the water supply of the territory, ie use water resources from other regions, through redistribution, for their economic activities. And for further economic development, significant infrastructure schemes are needed to redistribute water resources between regions. Kyiv region with the city of Kyiv and Odesa have a "high" water management dependence. These territories use from 71 to $100 \%$ of the water supply of the territory, ie almost the entire water potential of the territory. 


\section{Agricultural and Resource Economics: International Scientific E-Journal}

http://are-journal.com

It is important to understand, based on global research (Han et al., 2021; Qasemipour et al., 2020; Caparrós-Martínez et al., 2020; Wu et al., 2020), that the reduction of water supply in Ukraine is an important factor in growth net imports of virtual water into the country, reaching a certain limit (Roobavannan et al., 2020; Arunrat et al., 2020). According to statistics, in 2020 the share of food and agricultural raw materials in the structure of Ukrainian exports, for the first time in history, exceeded $50 \%$ of total export flows. Assuming that exports of food and agricultural raw materials continue to grow, the national economy will need to increase the use of water resources, which will be technologically impossible, and the import of virtual water from products that are not produced in large quantities in Ukraine.

Thus, it can be assumed that the economic growth of the Ukrainian economy due to the agricultural sector has its limits and is limited by water management dependence of the territories, ie the limitation of certain areas of Ukraine in terms of water resources. The next effective economic growth is possible only through the introduction of water-efficient technologies and intensification of water-efficient activities in the region.

Proof of this assumption is the lack of a correlation between the arithmetic mean for 10 years of fresh water use by region $\left(\mathrm{mln} \mathrm{m}^{3}\right)$ and the value of average long-term resources of river runoff in the regions $\left(\mathrm{km}^{3} /\right.$ year). Calculations have shown that, indeed, there is no connection between the water supply (water potential) of the regions and the use of fresh water by region.

At the same time, the index of regional water management dependence indicates the regions in which there is a dependence "deficit". The ratio of the existence of dependence on water resources "deficit" and the lack of connection between water supply (water potential) of regions and the use of fresh water by regions indicate that Ukraine has a peak load on water resources, after which further economic growth is possible only by due to the introduction of water-efficient technologies and intensification of water-efficient activities of the region in order to reduce the water capacity of agricultural products. This trend is confirmed by world studies (Anbar et al., 2020; Hao et al., 2021; Gómez-Limón et al., 2020; Shi, 2020).

Data for the Autonomous Republic of Crimea were not used in the calculations due to the temporary occupation and lack of data. For calculations such method of the correlation analysis as biserial correlation with use of point biserial Pearson correlation coefficient was used (Table 4).

According to this method, the variable $\mathrm{X}$ is measured on a strong scale, and the variable $\mathrm{Y}-$ on a dichotomous scale. Then the point biserial correlation coefficient is calculated by the formula:

$$
r_{p b}=\frac{\bar{x}_{1}-\bar{x}_{0}}{s_{x}} \cdot \sqrt{\frac{n_{1} n_{0}}{n(n-1)}},
$$

where $\bar{x}_{1}$ - average value for $X$ objects with a value of "unit" by $Y$;

$\bar{x}_{0}$ - average value for $X$ objects with a value of "zero" by $Y$; 
$s_{x}$ - average square deviation of all values by $X$;

$n_{1}$ - number of objects "unit" by $Y$;

$n_{2}$ - number of objects "zero" by $Y$;

$n=n_{1}+n_{0}-$ sample size.

It is also necessary to calculate the point biserial coefficient using other equivalent expressions:

$$
\begin{aligned}
& r_{p b}=\frac{\bar{x}_{1}-\bar{x}}{s_{x}} \cdot \sqrt{\frac{n_{1} n}{n_{0}(n-1)}}, \\
& r_{p b}=\frac{\bar{x}-\bar{x}_{0}}{s_{x}} \cdot \sqrt{\frac{n_{0} n}{n_{1}(n-1)}},
\end{aligned}
$$

where $\bar{x}$ - total average value for variable $X$.

Thus, the calculations of the correlation between the arithmetic mean value for 10 years of fresh water use by region $\left(\mathrm{mln}^{3}\right)$ and the value of the average long-term resources of river runoff in the regions $\left(\mathrm{km}^{3} /\right.$ year) are presented in table 4.

Table 4

Calculation of the correlation between the arithmetic mean value of fresh water use by region and the value of the average long-term resources of river runoff

\begin{tabular}{|c|c|c|c|c|c|c|c|}
\hline \multicolumn{2}{|c|}{$\begin{array}{l}\text { The value of the arithmetic } \\
\text { mean value for } 10 \text { years of fresh } \\
\text { water use by region, } \mathrm{mln}^{3}, x_{i}\end{array}$} & $\left(x_{i}-\bar{x}\right)^{2}$ & $Y 0$ & $Y 1$ & $\begin{array}{l}\text { Dichoto } \\
\text { scale }\end{array}$ & & $\begin{array}{c}\text { The value of the average } \\
\text { long-term resources of } \\
\text { river runoff in the regions, } \\
\mathrm{km}^{3} / \mathrm{year}, Y\end{array}$ \\
\hline \multicolumn{5}{|c|}{ Sample size: $n=24, \quad d f=22$} & \multicolumn{3}{|c|}{$n_{1}=14, \quad n_{0}=10$} \\
\hline Vinnytsia & 107.9 & 68018.81 & & 107.9 & high & 1 & 2.47 \\
\hline Volyn & 68.6 & 90062.51 & & 68.6 & high & 1 & 2.18 \\
\hline Dnipro & 1307.1 & 880586.74 & 1307.1 & & low & 0 & 0.87 \\
\hline Donetsk & 1324.8 & 914119.24 & 1324.8 & & low & 0 & 1.02 \\
\hline Zhytomyr & 141.2 & 51758.15 & & 141.2 & high & 1 & 3.15 \\
\hline Zakarpattia & 32.3 & 113167.76 & & 32.3 & high & 1 & 7.92 \\
\hline Zaporizhzhia & 1160 & 626149.10 & 1160 & & low & 0 & 0.62 \\
\hline Ivano-Frankivsk & 90.9 & 77175.16 & & 90.9 & high & 1 & 4.59 \\
\hline Kyiv & 1469.4 & 1211531.32 & & 1469.4 & high & 1 & 2.04 \\
\hline Kyrovohrad & 55.1 & 98347.57 & 55.1 & & low & 0 & 0.95 \\
\hline Luhansk & 162.8 & 42396.53 & 162.8 & & low & 0 & 1.46 \\
\hline Lviv & 161.3 & 43016.49 & & 161.3 & high & 1 & 4.92 \\
\hline Mykolaiv & 200.7 & 28225.40 & 200.7 & & low & 0 & 0.57 \\
\hline Odesa & 305.4 & 4007.42 & 305.4 & & low & 0 & 0.35 \\
\hline Poltava & 202.1 & 27756.95 & & 202.1 & high & 1 & 1.94 \\
\hline Rivne & 151.6 & 47134.22 & & 151.6 & high & 1 & 2.33 \\
\hline Sumy & 95.8 & 74476.68 & & 95.8 & high & 1 & 2.45 \\
\hline Ternopil & 60.5 & 94989.81 & & 60.5 & high & 1 & 1.81 \\
\hline Kharkiv & 302.7 & 4356.55 & & 302.7 & high & 1 & 1.66 \\
\hline Kherson & 933.1 & 318542.66 & 933.1 & & low & 0 & 0.14 \\
\hline Khmelnytsk & 92.7 & 76178.30 & & 92.7 & high & 1 & 2.14 \\
\hline Cherkasy & 218.1 & 22681.62 & 218.1 & & low & 0 & 1.01 \\
\hline Chenivtsi & 64.5 & 92540.18 & 64.5 & & low & 0 & 1.23 \\
\hline Chernihiv & 140.3 & 52168.46 & & 140.3 & high & 1 & 3.45 \\
\hline Amount & 8848.9 & 5059387.61 & 5731.6 & 3117.3 & $\mathrm{x}$ & & $\mathrm{x}$ \\
\hline
\end{tabular}
in the regions

Source: author's calculations. 


\section{Agricultural and Resource Economics: International Scientific E-Journal http://are-journal.com}

For further calculations it is necessary to find the mean values for the variable $X$ and the average square deviation $S_{x}$ and the value of the point biserial correlation coefficient. The hypothesis of the significance of the point biserial correlation coefficient was tested using the Student's test. In the statistical tables for the number of degrees of freedom $\mathrm{df}=22$ we need to find the critical values of the Student's criterion $t_{\alpha}(d f)$ (Table 5).

Table 5

Calculation of the mean values for the variable $X$, the average square deviation $S_{x}$, the value of the point biserial correlation coefficient and the empirical value of the Student's criterion

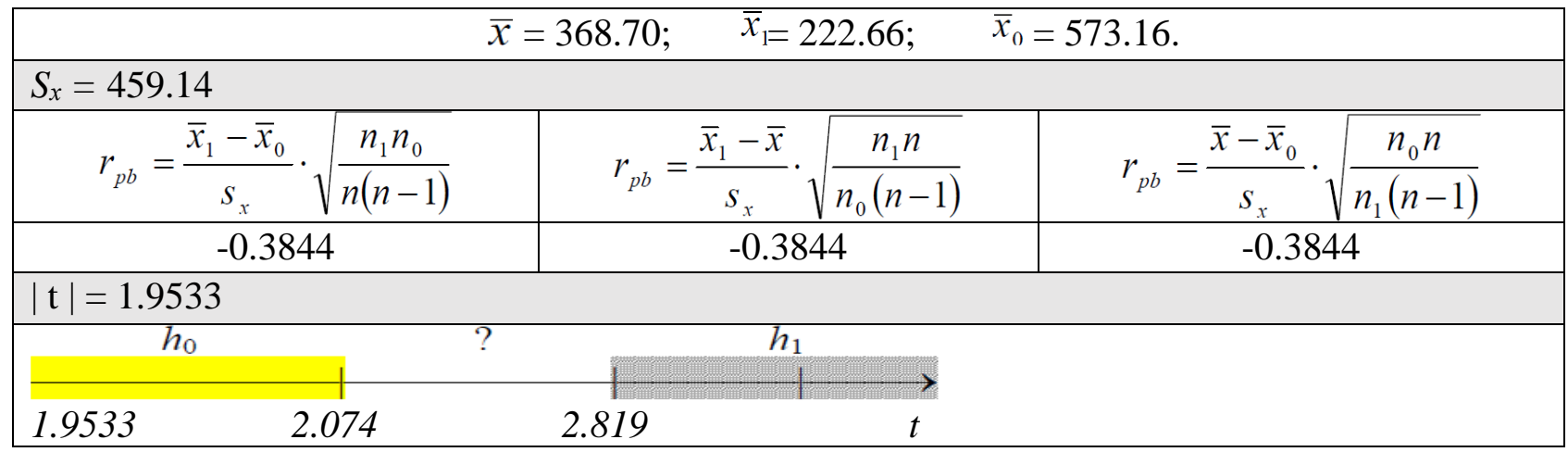

Source: author's calculations.

The empirical value of the Student's criterion is equal to

$$
|t|=\frac{\left|r_{p b}\right|}{\sqrt{1-r_{p b}^{2}}} * \sqrt{n-2}=\frac{|-0.3844|}{\sqrt{1-(-0.3844)^{2}}} * \sqrt{24-2}=1.9533
$$

Empirical value $|\mathrm{t}|=1.9533$ does not fall into the critical region, which allows us to accept the null hypothesis $\rho=0$.

Thus, there is no connection between the water supply (water potential) of the regions and the use of fresh water by region.

According to the world organizations - Food and Agriculture Organization of the United Nations (FAO, 2017); The World Water Council, AQUASTAT data (World Water Council, 2016) and the World Bank (2015, 2016, 2017), the so-called "influential countries", which are the world's major exporters of cereals, have a much lower average water intensity of GDP than Ukraine. Thus, in Australia this indicator is 17.634 thsd. $\mathrm{m}^{3} / \mathrm{USD}$; in France it amounts to 15.056 thsd. $\mathrm{m}^{3} / \mathrm{USD}$; Brazil has 32.996 thsd. $\mathrm{m}^{3} / \mathrm{USD}$; Canada -33.531 thsd. $\mathrm{m}^{3} / \mathrm{USD}$; USA -40.065 thsd. $\mathrm{m}^{3} / \mathrm{USD}$; Russia - 50.094 thsd. $\mathrm{m}^{3} / \mathrm{USD}$; Paraguay -54.786 thsd. $\mathrm{m}^{3} / \mathrm{USD}$; Argentina 106.186 thsd. $\mathrm{m}^{3} / \mathrm{USD}$; Ukraine -137.112 thsd. $\mathrm{m}^{3} / \mathrm{USD}$. And only Thailand and Pakistan have significantly higher figures, respectively, 182.485 thsd. $\mathrm{m}^{3} /$ USD and $1.698,272$ thsd. $\mathrm{m}^{3} / \mathrm{USD}$. Our calculations of the water intensity of GRP in Ukraine confirm the European data for Ukraine (Fedulova et al., 2019).

However, this coincidence of results indicates that it is necessary to take into account in future development plans, the state of infrastructure for water management in the regions, to stimulate water efficiency in the region in deepening the 
transformation of infrastructure, which should minimize the gross regional product (GRP), at least to the average value in Ukraine, to take into account the importance and value of water resources, which are becoming an expensive market commodity for both production and the population, as well as a safety factor. Large infrastructure projects require significant funds, which are currently lacking in Ukraine.

The analysis of the functioning of regional socio-economic systems under the influence of global challenges for efficient regional water use allows the authors to state the existence of a problem in infrastructure at the regional level. The modern world economy in the conditions of integration transformations actualizes the tendencies of regional development and determines that the regions are the driving force of the national economic system (Fedulova et al., 2020). The study of the transformation of the regional economy in the modern conditions of the geoeconomic space serves as a scientific basis for solving management problems, stimulating the development of regions and the country as a whole.

Ukraine has an exceptionally high share of effective territory in the total area of the country. With the exception of two Eurasian states - Russia and Turkey, Ukraine is the largest European country in area and length. The compact and developed territory of the country is characterized by the absence of extreme living conditions. Ukraine has the largest array of chernozems. The almost central position of Ukraine between the North Pole and the equator and the proximity of the warm sea create favorable comfortable conditions for human life and economic activity. Ukraine differs from European countries in the severity of the climate (the difference between summer and winter temperatures), and much of the agricultural land is located in the zone of risky agriculture. Capital construction, including the construction of foundations, wall thickness, water supply and heating networks in Ukraine is much more expensive than in other European countries due to the harsh climate.

Thus, global trends in spatial development demonstrate the need to take into account the limited water resources on the one hand, when developing regulatory policies for regional development, and their prospects for effective use on the other. The problem of infrastructure support on the way of regional and national growth becomes a priority.

Conclusions. In this study the main measures and documents that update the study of the problem of effective regional water use has been described. From research it is clear that initially humanity treated the water resource as a common good, not understanding its limitations and possible global scenarios for world development. But in 1992, at the 1st World Water Forum in Marrakech (Morocco), it was proclaimed that "water is a market, expensive commodity for which wars can be fough". The conducted theoretical analysis of the functioning of regional systems made it possible to state a change in the paradigm of regulation of regional development on the basis of water-efficiency and efficient regional water use.

Thus, the study defines the concept of water-efficient regional socio-economic system, so it is a socio-economic system that provides for the restoration of water resources in the region, reducing the water intensity of gross regional product (GRP) 


\section{Agricultural and Resource Economics: International Scientific E-Journal}

http://are-journal.com

and approaching European norms and proposes the classification of regions according to the index of regional water management dependence on the basis of its threshold values. A scientific and methodological approach to assessing the level of needs of regional socio-economic systems in water resources has been suggested, based on the application of the index of regional water management dependence, which is proposed to calculate the ratio of total fresh water use in the region to the volume of available river runoff in the region. parts of the water potential). The classification of regional socio-economic systems according to the level of water supply is developed, which is based on the definition of threshold values of the index of regional water management dependence.

The characteristic of water management dependence is given, from regions where only up to half of the water supply of the territory is used, and to regions where more than $100 \%$ of the water supply of the territory is used. The proposed classification showed that the economic complex in most regions is water-intensive and unbalanced, as well as does not provide restoration of water resources by environmental parameters and requires the introduction of infrastructure schemes for redistribution of water resources between regions for economic activity. It was found that in Dnipro, Donetsk, Zaporizhia and Kherson regions more than $100 \%$ of water supply of the territory is used, and in Kherson region this indicator is 5-7 times higher than this critical value. These areas have the characteristic of water management dependence "deficit", which means that they use more than $100 \%$ of the water supply of the territory, ie use water resources from other regions, through redistribution, for their economic activities. Thus, the situation has arisen that Ukraine, which does not have enough water resources, is now the so-called "influential country", which is the main world exporter of grain.

Using the method of correlation analysis (biserial correlation using Pearson point biserial correlation coefficient), the assumptions has been proved that economic growth of the Ukrainian economy due to the agricultural sector has its limits and is limited by water management dependence of territories, ie the limitation of certain territories of the regions of Ukraine in terms of water resources. The next effective economic growth is possible only through the introduction of water-efficient technologies and intensification of water-efficient activities in the region.

Therefore, further research should be aimed at the development of ways to activation of water efficiency in the region in terms of deepening the transformation of infrastructure. We propose to understand activation as an interdependent, interacting set of processes, ie a management system or a way to influence on promotion of water efficiency in the region in the form of methods, tools, levers that will ensure the reproduction of water capital and high welfare, improving physical and mental health. Future research may also take into account the use of groundwater in Ukraine. Groundwater in Ukraine accounts for $13.8 \%$ of the country's total water consumption. Unfortunately, the smallest amount of groundwater is in the agricultural regions of Ukraine $\left(0.28-0.43 \mathrm{~m}^{3} /\right.$ twenty-four hours - Dnipro, Odesa, Kyrovohrad, Donetsk, Mykolaiv, Zhytomyr and Vinnytsia regions). 


\section{Agricultural and Resource Economics: International Scientific E-Journal}

http://are-journal.com

\section{References}

1. Allan, J. A. (1998), Virtual water: a strategic resource. Global solutions to regional deficits. Groundwater, vol. 36, is. 4, pp. 545-546. https://doi.org/10.1111/j.1745-6584.1998.tb02825.x.

2. Anbar, A. H., Abu-Dalhoum, M., Maslamani, A., Al Antary, T. M. and Sawwan, J. (2020), Agricultural patterns in Jordan: a new analytical approach. Fresenius Environmental Bulletin, vol. 29, no. 12, pp. 11006-11016.

3. Arunrat, N., Pumijumnong, N., Sereenonchai, S., Chareonwong, U. and Wang, C. (2020), Assessment of climate change impact on rice yield and water footprint of large-scale and individual farming in Thailand. Science of the Total Environment, vol. 726, 137864. https://doi.org/10.1016/j.scitotenv.2020.137864.

4. Bretschger, L. and Vinogradova, A. (2019), Best policy response to environmental shocks: applying a stochastic framework. Journal of Environmental Economics and Management, vol. 97, pp. 23-41. https://doi.org/10.1016/j.jeem.2017.07.003.

5. Bacon, D. (2017), The MENA region, the virtual water trade, and the opportunity cost of agriculture. Leiden University, Netherlands.

6. Cabinet of Ministers of Ukraine (2014), Resolution of the Cabinet of Ministers of Ukraine "On approval of the State Strategy for Regional Development until 2020", available at: http://zakon2.rada.gov.ua/laws/show/385-2014-\%D0\%BF.

7. Caparrós-Martínez, J. L., Rueda-Lópe, N., Milán-García, J. and de Pablo Valenciano, J. (2020), Public policies for sustainability and water security: the case of Almeria. Global Ecology and Conservation, vol. 23, e01037. https://doi.org/10.1016/j.gecco.2020.e01037.

8. Dinar, S. (2007), Water Wars? Conflict, cooperation, and negotiation over transboundary water in Water: A Source of Conflict or Cooperation? ed V. I. Glover, Science Publishers, Enfield, UK.

9. Fedulova, S., Dubnytskyi, V., Komirna, V. and Naumenko, N. (2019), Economic development management in a water-capacious economy. Problems and Perspectives in Management, vol. 17, is. 3, pp. 259-270. https://doi.org/10.21511/ppm.17(3).2019.21.

10. Fedulova, S. O. and Pivovarov, O. A. (2017), Ekonomika pidpryyemstv vodopostachannya ta vodovidvedennya [Economy of enterprises of water supply and sewage: training. manual], SHEI "Ukrainian State University of Chemical Technology", Dnipro, Ukraine.

11. Fedulova, S., Pivovarov, O., Khudolei, V., Komirna, V. and Kalynovskyi, A. (2020), Water infrastructure and economic security of regional socio-economic systems: evidence from Ukraine. Problems and Perspectives in Management, vol. 18, is. 2, pp. 166-179. https://doi.org/10.21511/ppm.18(2).2020.15.

12. Global future trends 2030: alternative worlds (2013), Publication of the National Intelligence Council of the USA (O. K. Usmanova Trans.), ICWC Science and Information Center, Tashkent, Uzbekistan.

13. Gómez-Limón, J. A., Gutiérrez-Martín, C. and Montilla-López, N. M. 
(2020), Agricultural water allocation under cyclical scarcity: the role of priority water rights. Water, vol. 12, is. 6, 1835. https://doi.org/10.3390/w12061835.

14. Han, X., Zhao, Y., Gao, X., Jiang, S., Lin, L. and An, T. (2021), Virtual water output intensifies the water scarcity in Northwest China: current situation, problem analysis and countermeasures. Science of the Total Environment, vol. 765, 144276. https://doi.org/10.1016/j.scitotenv.2020.144276.

15. Hao, X., Yan, J., Sha, J., Ke, W., He, G., Song, C., Ma, Y. and Zhang, G. (2021), Exploring the synthetic optimal policies for solving problems of agricultural water use with a dynamic optimization simulation model. Journal of Cleaner Production, vol. 287, 125062. https://doi.org/10.1016/j.jclepro.2020.125062.

16. Jacyk, A. V., Grishchenko, Y. M., Volkova, L. A. and Pashenyuk, I. A. (2007), Vodni resursy: vykorystannya, okhorona, vidtvorennya, upravlinnya [Water resources: use, protection, reproduction, management], Kyiv, Genesis, Ukraine.

17. Jacyk, A. V., Tomiltseva, A. I., Mokin, V. B. el al. (2017), Ekolohichni osnovy upravlinnya vodnymy resursamy [Environmental Basics of Water Management], Instytut ekolohichnoho menedzhmentu ta staloho vykorystannya, Kyiv, Ukraine.

18. Melina, G., Yang, S. S. and Zanna, F. L. (2016), Debt sustainability, public investment and natural resources in developing countries: the DIGNAR model. Economic Modelling, vol. 52, pp. 630-649. https://doi.org/10.1016/j.econmod.2015.10.007.

19. Mishra, V. K., Palleti, V. R. and Mathur, A. (2019), A modeling framework for critical infrastructure and its application in detecting cyber-attacks on a water distribution system. International Journal of Critical Infrastructure Protection, vol. 26, 100298. https://doi.org/10.1016/j.ijcip.2019.05.001.

20. Morris, J. and McGuinness, M. (2019), Liberalisation of the English water industry: what implications for consumer engagement, environmental protection, and water security? Utilities Policy, vol. 60,100939. https://doi.org/10.1016/j.jup.2019.100939.

21. Official website of Food and Agriculture Organization of the United Nations (FAO) (n.d.), available at: http://www.fao.org.

22. Official website of Institute of World Resources. (n.d.), available at: http://www.wri.org.

23. Official website of State Statistics Service of Ukraine (n.d.), available at: http://www.ukrstat.gov.ua.

24. Official website of World Bank Annual (n.d.), Reports for 2015; 2016; 2017, available at: http://www.worldbank.org.

25. Official website of World Water Council (n.d.), available at: http://www.worldwatercouncil.org.

26. Official website of World Water Institute (SIWI) (n.d.), available at http://www.siwi.org.

27. Oki, T., Yano, S. and Hanasaki, N. (2017), Economic aspects of virtual water trade. Environmental Research Letters, vol. 12, no. 4, 044002. 
https://doi.org/10.1088/1748-9326/aa625f.

28. Perelyot, R. A. (2010), Vodnyy defitsit $i$ ekonomika effektivnosti ispol'zovaniya vody [Water scarcity and the economy of water efficiency] in "Rational management of nature: international programs, Russian and foreign experience". Obshchestvo nauchnykh znaniy KMK, Moscow, Russia.

29. Qasemipour, E., Tarahomi, F., Pahlow, M., Sadati, S. S. M. and Abbasi, A. (2020), Assessment of virtual water flows in Iran using a multi-regional input-output analysis. Sustainability, vol. 12, is. 18, 2534. https://doi.org/10.3390/su12187424.

30. Roobavannan, M., Kandasamy, J., Pande, S., Vigneswaran, S. and Sivapalan, M. (2020), Sustainability of agricultural basin development under uncertain future climate and economic conditions: a socio-hydrological analysis. Ecological Economics, vol. 174,

106665. https://doi.org/10.1016/j.ecolecon.2020.106665.

31. Shi, X. (2020), Research on the influence of trade circulation on coastal agricultural economic growth. Journal of Coastal Research, vol. 115, spec. is. 1, pp. 96-98. https://doi.org/10.2112/JCR-SI115-029.1.

32. State Statistics Service of Ukraine (2010), Dovkillya Ukrayiny. Statystychnyy byuleten [Environment of Ukraine. Statistical bulletin], State Statistics Service of Ukraine, Kyiv, Ukraine.

33. State Statistics Service of Ukraine (2014), Dovkillya Ukrayiny. Statystychnyy byuleten [Environment of Ukraine. Statistical bulletin], State Statistics Service of Ukraine, Kyiv, Ukraine.

34. State Statistics Service of Ukraine (2017), Dovkillya Ukrayiny. Statystychnyy byuleten [Environment of Ukraine. Statistical bulletin], State Statistics Service of Ukraine, Kyiv, Ukraine.

35. State Statistics Service of Ukraine (2015), Pro vykorystannya vody v Ukrayini ta rehionakh. Statystychnyy byuleten [About the use of water in Ukraine and regions. Statistical bulletin], State Statistics Service of Ukraine, Kyiv, Ukraine.

36. State Statistics Service of Ukraine (2016), Pro vykorystannya vody v Ukrayini ta rehionakh. Statystychnyy byuleten [About the use of water in Ukraine and regions. Statistical bulletin], State Statistics Service of Ukraine, Kyiv, Ukraine.

37. State Statistics Service of Ukraine (2017), Sil's'ke hospodarstvo Ukrainy 2017. Statystychnyj zbirnyk [Agriculture of Ukraine 2017. Statistical yearbook], State Statistics Service of Ukraine, Kyiv, Ukraine.

38. State Statistics Service of Ukraine (2018), Roslynnytstvo v Ukrayini. Statystychnyy byuleten [Plant Growing in Ukraine. Statistical bulletin], State Statistics Service of Ukraine, Kyiv, Ukraine.

39. van Beek, E. and Lincklaen Arriens, W. (2014), Water Security: putting the concept into practice. TEC background papers no. 20. Global Water Partnership (GWP), Stockholm, Sweden.

40. Water: fit to finance? Catalyzing national growth through investment in water security (2015), Report of the High Level Panel on Financing Infrastructure for a Water-Secure World. Organisation for Economic Co-operation and Development 
(OECD), World Water Council, Marseille, France.

41. Water Resources Management in Uncertainty and Risk (2012), Overview of Important Messages of the 4th Report on the Development of Water Resources of the World (WWDR4), available at: http://www.unesco.org/new/en/naturalsciences/environment/water/wwap/wwdr/wwdr4-2012.

42. Wehn, U. and Montalvo, C. (2018), Exploring the dynamics of water innovation: foundations for water innovation studies. Journal of Cleaner Production, vol. 171, pp. 1-19. https://doi.org/10.1016/j.jclepro.2017.10.118.

43. Wichelns, D. (2010), An economic analysis of the virtual water concept in relation to the agri-food sector. Hanover college, Indiana, USA.

44. Wu, Z., Zhang, Y., Hua, Y., Ye, Q., Xu, L. and Wang, S. (2020), An improved system dynamics model to evaluate regional water scarcity from a virtual water perspective: a case study of Henan Province. Sustainability, vol. 12, is. 18, 7517. https://doi.org/10.3390/su12187517.

45. Yang, H., Reichert, P., Abbaspour, K. C. and Zehnder, A. J. B. (2003), A water resources threshold and its implications for food security. Environmental Science and Technology, vol. 37, is. 14, pp. 3048-3054. https://doi.org/10.1021/es0263689.

46. Yang, H., Wang, L. and Zehnder, A. J. B. (2007), Water scarcity and food trade in the Southern and Eastern Mediterranean countries. Food Policy, vol. 32, is. 5-6, pp. 585-605. https://doi.org/10.1016/j.foodpol.2006.11.004.

\section{Citation:}

Стиль-ДСТУ:

Fedulova S., Dubnytskyi S., Naumenko N., Komirna V., Melnikova I., Agabekov B. Effective economic growth under conditions of regional water management dependence. Agricultural and Resource Economics. 2021. Vol. 7. No. 1. Pp. 22-43. https://doi.org/10.51599/are.2021.07.01.02.

Style-APA:

Fedulova, S., Dubnytskyi, S., Naumenko, N., Komirna, V., Melnikova, I. and Agabekov, B. (2021), Effective economic growth under conditions of regional water management dependence. Agricultural and Resource Economics, vol. 7, no. 1, pp. 22-43. https://doi.org/10.51599/are.2021.07.01.02. 